\title{
Identification of Locations for Potential Glacial Lakes Formation using Remote Sensing Technology
}

\author{
Yagol P. ${ }^{1}$, Manandhar A. ${ }^{2}$, Ghimire P. ${ }^{3}$, Kayastha R.B. ${ }^{4}$, Joshi J. R. ${ }^{5}$ \\ ${ }^{1}$ Survey Officer Survey Department \\ ${ }^{2}$ Survey Engineer, Upper Tamakoshi, Hydropower Ltd. \\ ${ }^{3}$ Instructor, Land Management Training Center, Dhulikhel, Kavre \\ ${ }^{4}$ Asst. Professor, Kathmandu University, Dhulikhel \\ ${ }^{5}$ Director, Land Management Training Center, Dhulikhel, Kavre
}

\section{Keywords}

Glacial Lake, Remote Sensing, COSI-Corr.

\begin{abstract}
In past Nepal has encountered a number of glacial lake outburst flood (GLOF) events causing loss of billions of rupees. Still there are a number of glacial lakes forming and there are chances of new glacial lake formation. Hence there is intense need to monitor glaciers and glacial lakes. The development on remote sensing technology has eased the researches on glacier and glacial lakes. Identification of locations of potential glacial lakes through the use of remote sensing technology has been proven and hence is opted for identification of locations of potential glacial lake in Khumbu Valley of Sagarmatha Zone, Nepal. The probable sites for glacial lake formation are at Ngojumpa, Lobuche, Khumbu, Bhotekoshi, Inkhu, Kyasar, Lumsumna, etc. As per study, the biggest glacial lake could form at Ngozumpa glacier. Even in other glaciers potential supra-glacial lakes could merge together to form lakes that occupy significant area.
\end{abstract}

\section{Introduction}

In past 40 years, Nepal has encountered more than 13 huge GLOFs with many villages destroyed, many human lives taken away, many infrastructures like hydropower station, mini hydropower plant, and bridges collapsed causing loss of billions of rupees (Ives et al., 2010). The studies report formation of a number of glacial lakes due to speeded glacier retreat (Ives et al., 2010). And there are lot more chances of new glacial lake formation which might eventually lead to natural hazards, justifying the necessity to identify potential glacial lakes.

Remote sensing-based measurements provide the platform to monitor the glacier and glacial lakes and could be used for identification of possible glacial lakes (Frey et al., 2010). The technology not only eases the researchers and academics by making measurements readily available without having to tread those seldom accessible glaciers and glacial lakes but provides possibly complete coverage.

In the article, we use remote sensing technology for the identification of locations for potential glacial lake formation.

\subsection{Study Area}

The area of study is the glaciers of Khumbu Valley of Solukhumbu District of Sagarmatha Zone, Nepal. Khumbu Valley extends from $27^{\circ} 38^{\prime} 58^{\prime \prime} \mathrm{N}$ to $28^{\circ}$ $6^{\prime} 46^{\prime \prime} \mathrm{N}$ latitude and $86^{\circ} 30^{\prime} 52^{\prime \prime} \mathrm{E}$ to $86^{\circ} 59^{\prime} 09^{\prime \prime} \mathrm{E}$ longitude and consists of three VDCs namely Khumjung, Namche and Chaurikharka. The total area covered by Khumbu Valley is 1475.4 square kilometers.

Khumbu Valley consists of the highest peak of the world, Mt. Everest and Namche VDC of Khumbu Valley is regarded as the gateway to Mt. Everest. Khumbu Valley also consists of the longest active glacier of Nepal, Ngojumpa glacier. Sacred Gokyo Lake and Sagarmatha National Park are also situated in this Valley. 


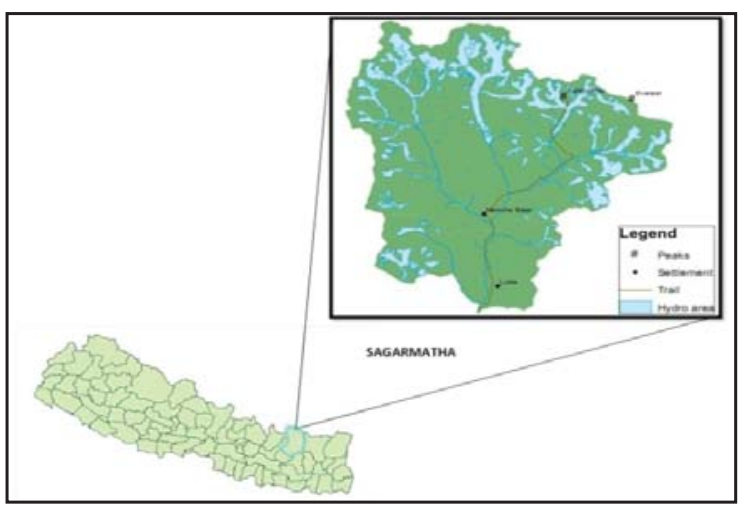

Figure 1: Study Area

The valley shelters more than hundred glaciers among which 31 are identifiable through remote sensing. The glaciers that can be identified through remote sensing are Amadablam, Ambulapcha, Bhotekoshi, Chhule, Chola, Cholotse, Churo, Duwo, Gaunara, Goraksep, Imja, Inkhu, Khangri Nup, Khangri Shar, Khumbu, Kyasar, Landak, Lanmuche, Lhotse, Lhotse Nup, Lhotse Shar, Lobuche, Lumdin, Lumsumna, Melun, Minbo, Nare, Ngojumpa, Nuptse, Thyanbo and Tobuche.

\section{Method And Materials}

The possible glacial lakes are determined by selecting the area with slope below threshold slope which is also called slope criteria and area with the velocity below threshold velocity. The result can be more refined through manual application geographic association criteria; distinct slope increase, reduction of glacier width, and crevasse-free part followed by heavily crevassed part (Frey et al., 2010). However the geographic association criteria are for detection of overdeepenings on glacier bed.

The glacial lakes, in Himalaya, are found to be developed usually at the tongue of debris covered glaciers due to negative mass balance by down wasting rather than retreating (Richardson, 2010). According to the studies by Reynolds (2000) on Glacial Lakes of Bhutan, the large glacial lakes were found to be developed on the places in glaciers having surface slope less than $2^{\circ}$ which was later on supported by Quincey et al. (2007).Quincey et al. (2007), in the research on the possibility of formation of glacial lakes in Himalaya, applied slope below $2^{\circ}$ as glacial slope threshold criteria. The research also found that the glacial lakes were found to form at the regions of glaciers with the surface velocity less than $10 \mathrm{~m} / \mathrm{a}$. The formation of glacial lakes with the glacier velocity over $10 \mathrm{~m} / \mathrm{a}$ are not likely as there is high possibility of draining out (Quincey et al., 2007). But the study of European Alps found the surface slope less than $5^{\circ}$ as a criteria for glacial lakes forming at the glaciers parts with overdeepened bed that are caused by the previous glaciers. But the research didn't use the velocity as the determinant of glacial lake but geographic association, such as distinct slope increase, reduction of glacier width, and crevasse-free part followed by heavily crevassed part, was used. These geographic association criteria are for detection of overdeepenings on glacier bed and the study reported the high possibility of formation of glacial lakes on these overdeepenings (Frey et al., 2010).

This article will use both the criteria defined by Reynolds (2000), Quincey et al. (2007) and Frey et al. (2010) to find out the possible glacial lakes in Khumbu Valley for comparative analysis. The overall methodology for glacial lake prediction is illustrated in the Figure 2.

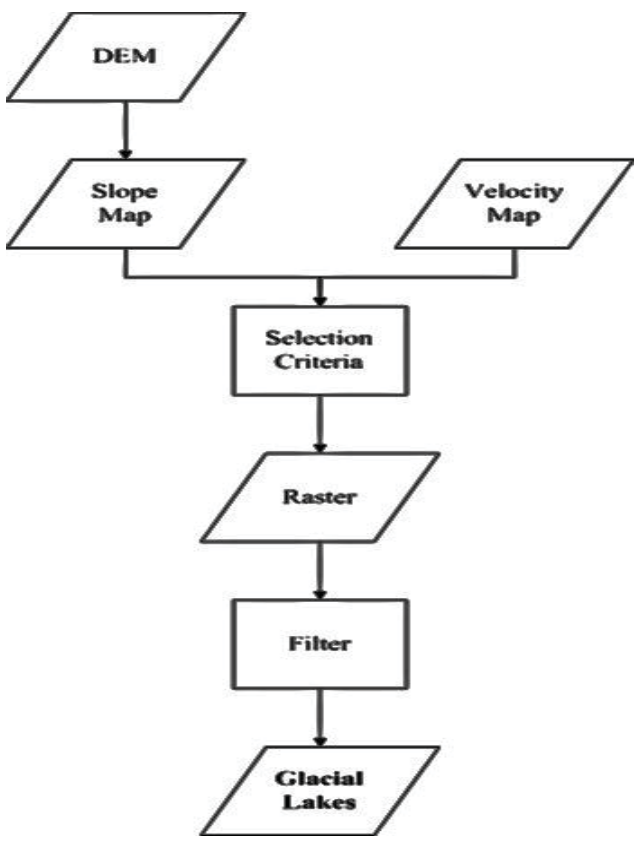

Figure 2: Overall Process for Identification of Locations of Potential Glacial Lakes 


\subsection{Materials Used}

SPOT 5 satellite imageries of Level A for 2010 and 2009 was used was used for the deriving surface velocity of glacier using COSI-Corr (Co-registration of optically sensed image and correlation, Leprince et al. 2007). Digital elevation model (DEM) required for the COSI-Corr technique and preparation of slope map was produced from the contour map of $40 \mathrm{~m}$ interval produced by Department of Survey, GoN.

\subsection{Inventory of glaciers}

The inventory of glaciers was prepared by manual digitization of glaciers over the image of 2010. The inventory contains 31 glaciers. The names of the glaciers are derived from the topographic map of Pumori, Namche Bazar and Solukhumbu.

At first, attempts were made to prepare the inventory through classification of the image of 2010. In order to classify glaciers, we also calculated Normalized Difference Snow Index (NDSI) of 2010 image from which we were able to differentiate snow and clouds but as the glaciers as well as the hills were covered with snow, it hindered the classification, both supervised and unsupervised, due to separate classes being spectrally similar. Moreover, the study area contains many debris-covered glaciers so the inventory was prepared through manual digitization.

\subsection{Slope and Velocity Map Preparation}

The preparation of slope map and velocity map is essential, as this study uses slope and velocity threshold to predict the formation of glacial lakes in the study area.

The slope map was prepared from the DEM (Figure 3). This DEM was prepared from the contour map of contour interval $40 \mathrm{~m}$, obtained from the Department of Survey, GoN.

The velocity map (Figure 4) was produced from orthorectification, co-registration and correlation (COSI-Corr technology) of satellite images of year 2010 and 2009 of area under study. The satellite image of 2010 was orthorectified with respect

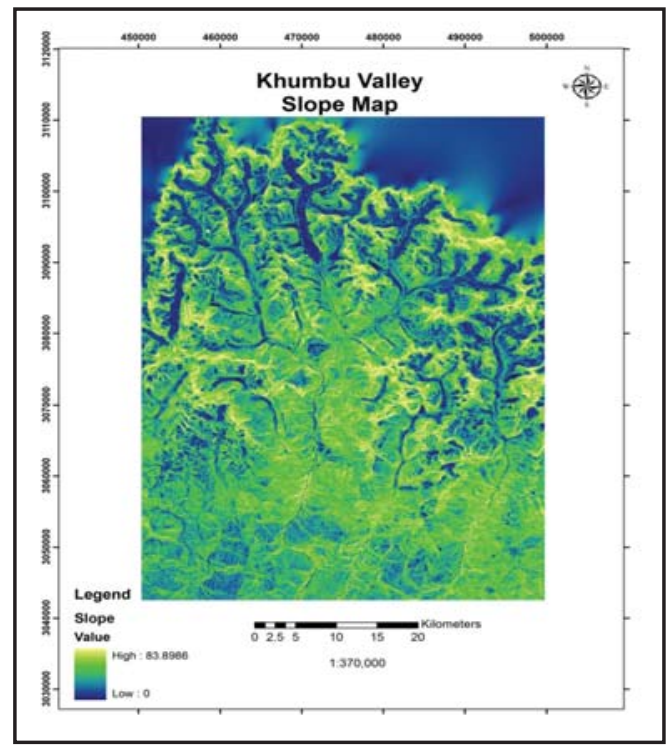

Figure 3: Slope Map of Khumbu Valley (Scale not as mentioned)

to the DEM and that of 2009 was orthorectified with respect to orthorectified image of 2010. Now these orthorectified images were correlated and the displacement maps were produced which after omitting outliers were subjected to the calculation to give velocity map as output. The formula for calculation of the velocity map out of displacement map is,

$$
\mathrm{V}=\mathrm{D} / \mathrm{T}
$$

Where $\mathrm{D}=$ Displacement, $\mathrm{T}=$ Time interval between the acquisitions of two images.

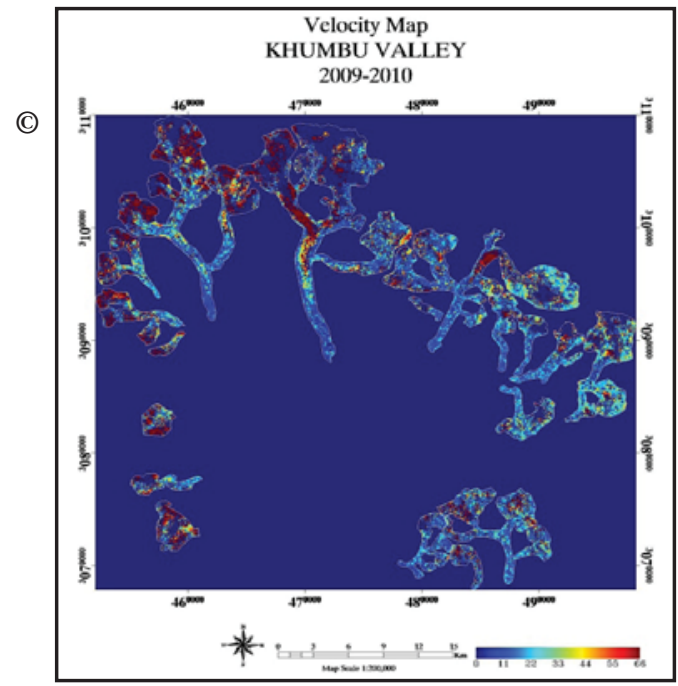

CNES (2008), distribution Spot image S. A.

Figure 4: Velocity Map of Khumbu Valley Glaciers (Scale not as mentioned) 


\subsection{Model of possible glacial lakes}

The conditional raster was prepared by selecting the region whose slope is less than $2^{\circ}$ and velocity less than $10 \mathrm{~m} / \mathrm{a}$. Similarly another raster was prepared whose slope was less than $5^{\circ}$ and velocity less than $10 \mathrm{~m} / \mathrm{a}$. These conditional raster were prepared in reference to the criteria proposed by Reynold (2000), Quincey et al. (2007) and Frey et al. (2010). Reynold (2000) and Quincey et al. (2007) proposed the slope criteria for formation of glacial lake to be below $2^{\circ}$ while Frey et al. (2010) proposed it to be below $5^{\circ}$. Quincey et al. (2007) proposed the velocity criteria for the formation of glacial lakes to be below $10 \mathrm{~m} / \mathrm{a}$. From the above criteria, the possible sites for the glacial lake formation were derived. The produced output is a rough estimate of the potential sites for glacial lake formation. This output was further processed using various filters such as removing the pixels with less count values and polygonising the remaining pixels to prepare possible glacial lakes formation model.

\section{Results And Discussion}

The predicted model of glacial lakes formation with slope below $2^{\circ}$ and velocity below $10 \mathrm{~m} / \mathrm{a}$, and with slope below $5^{\circ}$ and velocity below $10 \mathrm{~m} / \mathrm{a}$ are shown in Figure 5 and Figure 6, respectively.@ CNES (2008), distribution Spot image S. A.

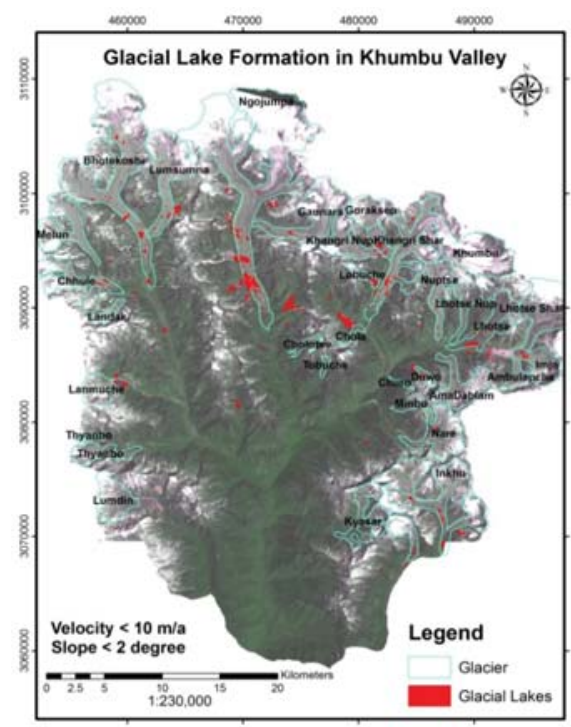

Figure 5: Locations and area covered by potential glacial lakes (Scale not as mentioned) for slope $<2{ }^{\circ}$

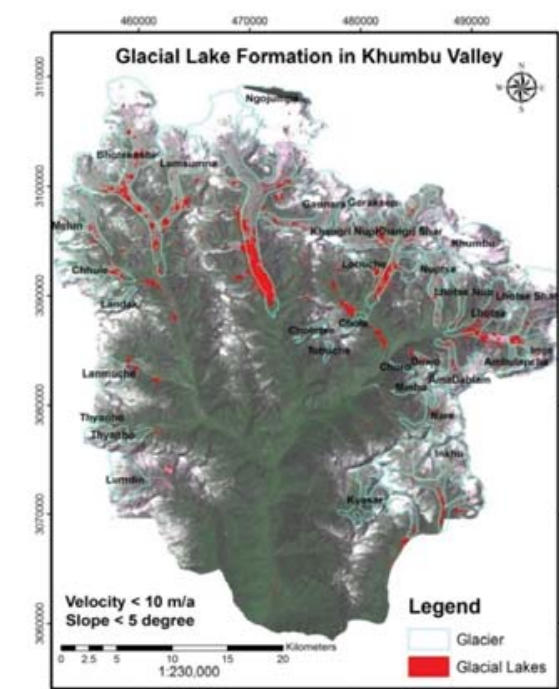

(C) CNES (2008), distribution Spot image S. A.

Figure 6: Locations and area covered by potential glacial lakes (Scale not as mentioned) for slope $<2^{\circ}$

The probable sites for glacial lake formation are at Ngojumpa, Lobuche, Khumbu, Bhotekoshi, Inkhu, Kyasar, Lumsumna, etc. It is seen that the probable sites for glacial lake formation for each glacier are more in the terminus region than in the head region. The reason behind it is that in the head region, both the slope as well as the velocity is higher compared to that of the terminus region. The estimated area (in sq. $\mathrm{km}$.) of the potential glacial lakes in Khumbu Valley with slope less than $2^{\circ}$ and velocity less than $10 \mathrm{~m} / \mathrm{a}$ is shown in the Figure 7.Similarly the estimated area (in sq. km.) of the potential glacial lakes in Khumbu Valley with slope less than $5^{\circ}$ and velocity less than $10 \mathrm{~m} / \mathrm{a}$ is shown in the Figure 8. These estimated areas of glacial lakes don't include the area of the existing glacial lakes. The glaciers with the existing glacial lakes are enlisted in Table $\mathbf{1}$.

As per the study, the biggest glacial lakes can form in Ngojumpa glacier. Under the criteria of slope threshold less than $5^{\circ}$ and velocity threshold less than $10 \mathrm{~m} / \mathrm{a}$, the total area that can be occupied by the lake is around $7.19 \mathrm{Sq} . \mathrm{km}$. The single huge lake will be formed from 1200 meters to 7500 meters from the terminus resulting on the formation of huge glacial lake (Figure 9). According to study, there should already have formed glacial lake in Ngojumpa glacier, but in reality it is not so. This suggests that the prediction of glacial lakes cannot be done just by observing slope and velocity. 


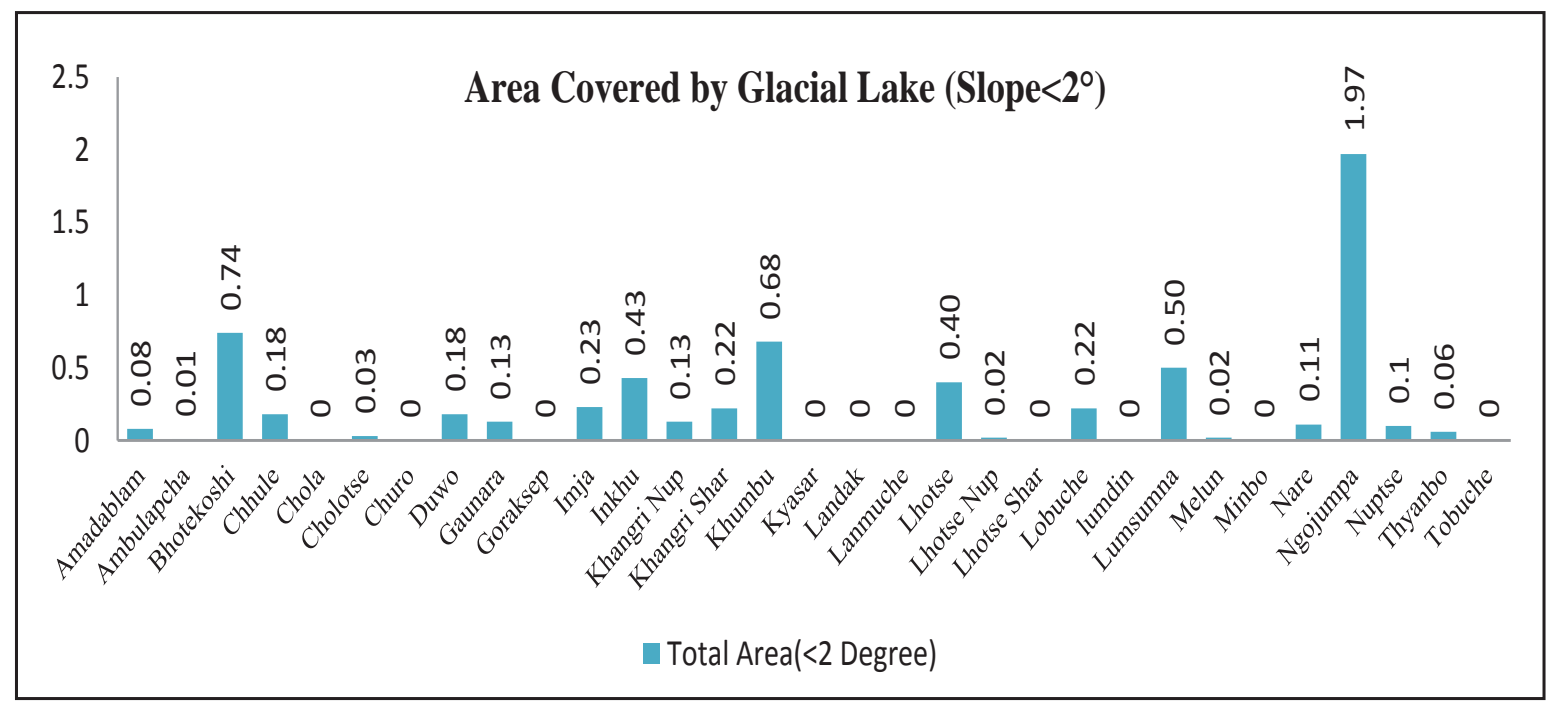

Figure 7: Area covered by glacial lake for slope $<2^{\circ}$

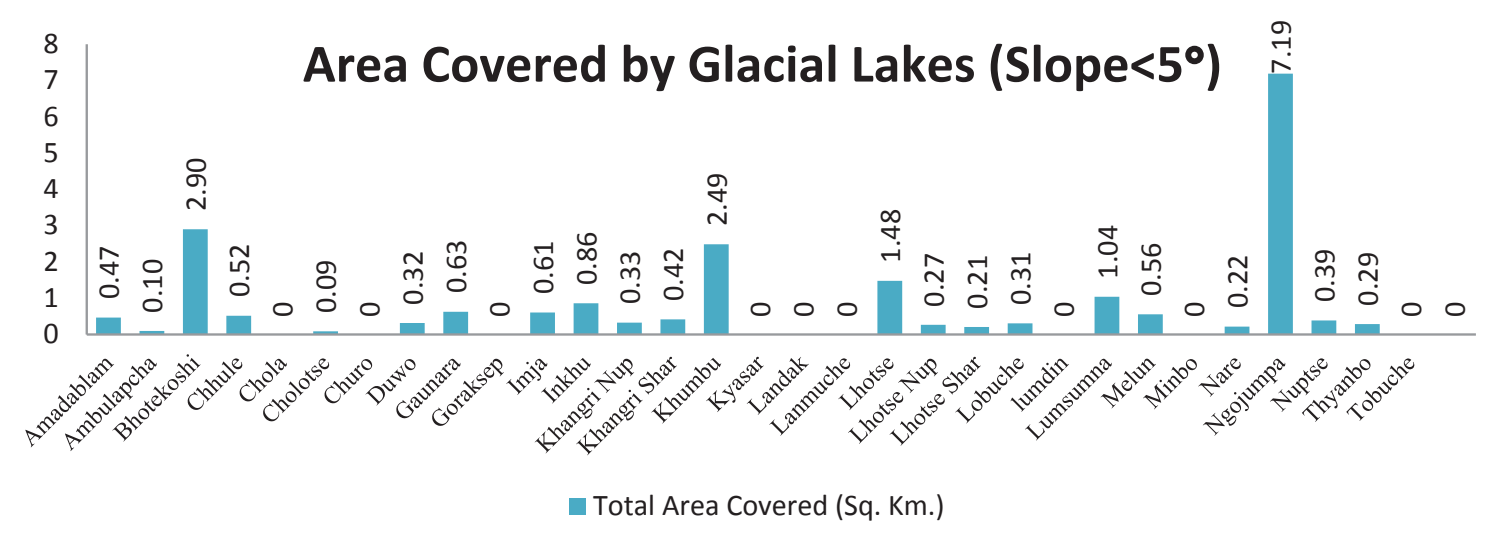

Figure 8: Area covered by glacial lake for slope $<5^{\circ}$

\begin{tabular}{|l|l|l|l|}
\hline S.N & Glaciers & Glacial Lakes & Type \\
\hline 1. & Chola & Chola Cho & Lateral Moraine \\
\hline 2. & Imja & Imja Cho & End Moraine \\
\hline 3. & Kyasar & Kyasar Cho & End Moraine \\
\hline 4. & Lanmuche & Dig Cho & End Moraine \\
\hline 5. & Lumdin & Lumdin Cho & End Moraine \\
\hline 6. & Ngojumpa & $\begin{array}{l}\text { Thonak Cho, DudhPokhari, } \\
\text { Toujun Cho }\end{array}$ & Lateral Moraine \\
\hline
\end{tabular}


Additional information about glacier characteristics, topography should be included while observing, so as to achieve more realistic results. In case of some glaciers, a number of supra-glacier lakes are predicted to form. Moreover those possible supra-glacier lakes have the possibility of expanding to form a huge glacial lake in future. Figure 10 illustrates the supraglacial lakes that can form in the Lhotse. These supra-glacier lakes can combine together to form a single huge lake within the glacier.

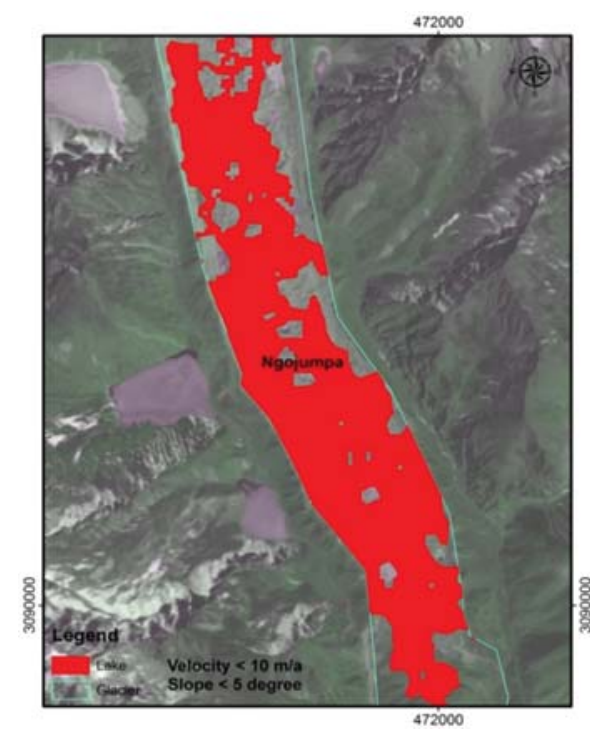

(c) CNES (2008), distribution Spot image S. A.

Figure 9: Potential glacial lake in Ngojumpa Glacier

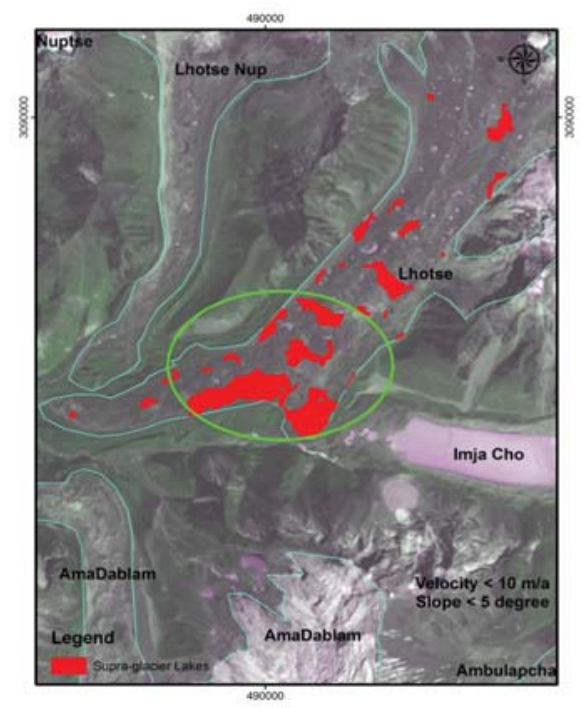

(C) CNES (2008), distribution Spot image S. A. Figure 10: Potential glacial lake in Lhotse Glacier
The study shows even in the glaciers with existing glacial lakes, there is possibility of formation of supraglacial lakes increasing the possibility of expansion of the existing ones. Typically this characteristic is seen in the Imja glacier. There is a glacial lake Imja Cho at the terminus of the Imja glacier. Three glaciers Imja, Lhotse Shar and Ambulapcha contribute to this lake. The study shows that there is still a chance of formation of supra-glacier lakes at the junction of these three glaciers just above the Imja Cho (Figure 11). These lakes in future can terminate into Imja Cho resulting on its expansion and increased risk of GLOF.

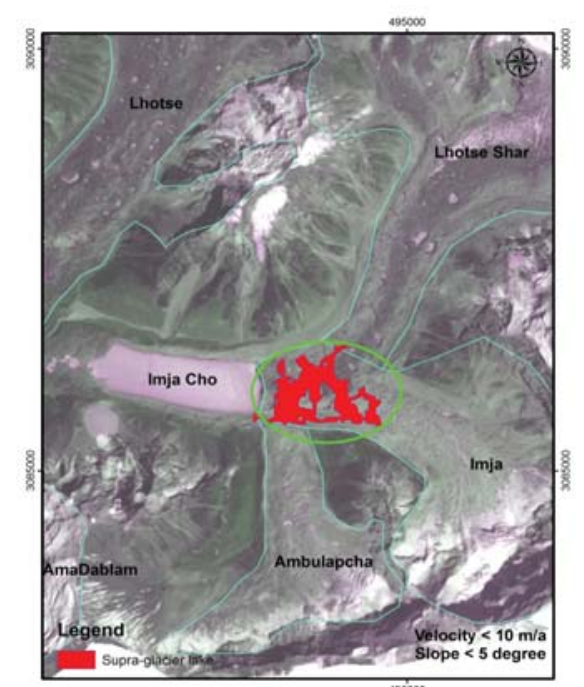

(C) CNES (2008), distribution Spot image S. A. Figure 11: Potential glacial lake at Imja Glacier

\subsection{CONCLUSION}

The study shows that there is possibility of formation of glacial lakes at glaciers; Ngojumpa, Lobuche, Khumbu, Bhotekoshi, Inkhu, Kyasar, Lumsumna, etc. Among all the glaciers, the biggest glacial lake could possibly form at Ngojumpa glacier which will cover around 7.19 sq. $\mathrm{Km}$. of area if the threshold criteria proposed by Frey et al. 2010 used or 1.97 sq. $\mathrm{Km}$. of area if the threshold criteria defined by Reynold, 2000 is used. It is seen that in some glaciers there are chances of forming a number of potential supra-glacial which within a single glacier could 
merge together to form a huge lake. This study also concludes with the potentiality of remote sensing technology for glacial study.

\section{References}

1. Frey, H., Haeberli, W., Linsbauer, A., Huggel, C., and Paul, F. (2010). A multi-level strategy for anticipating future glacier lake formation and associated hazard potentials. Natural Hazards and Earth System Sciences 10, 339-352.

2. Ives, J.D., Shrestha, R.B., Mool, P.K.(2010). Formation of Glacial Lakes in the Hindu KushHimalaya and GLOF Risk Assessment, Kathmandu: ICIMOD.

3. Leprince S., Ayoub F., Klinger Y., Avouac J. P. (2007). Co-Registration of Optically Sensed Images and
Correlation(COSI-Corr): an Operational Methodology for Ground Deformation Measurements.

4. Quincey, D. J., Richardson, S. D., Luckman, A., Lucas, R. M., Reynolds, J. M., Hambrey, M. J., and Glasser, N. F. (2007). Early recognition of glacial lake hazards in the Himalaya using remote sensing datasets. Global and Planetary Change, 56, 137-152.

5. Reynolds, J. M. (2000). On the formation of supraglacial lakes on debris-covered glaciers. In "Debris-Covered Glaciers." (M. Nakawo, C. F. Raymond, and A. Fountain, Eds.). IAHS Publication No.264, IntAssoc Hydrological Sciences, Wallingford. 153-161.

6. Richardson S. D. (2010).Remote sensing approaches for early warning of GLOF hazards in the Hindu Kush-Himalayan region. UN/ISDR

\section{Principal Author's Information}

Name

Academic Qualification

Organization

Current Designation

Work Experience

Published Papers/Articles

Email :shr-pravesh@hotmail.com

\section{Mr. Pravesh Yagol}

BE in Geomatics Engineering, KU.

: Cadastral Survey Branch, Survey Department

: Survey Officer

: 2 Years 